\title{
OPEN Influence of native ureolytic microbial community on biocementation potential of Sporosarcina pasteurii
}

\author{
Raja Murugan $^{1,2}$, G. K. Suraishkumar ${ }^{1}$, Abhijit Mukherjee ${ }^{2} \&$ Navdeep K. Dhami $^{2 \bowtie}$
}

Microbially induced calcium carbonate precipitation (MICP)/Biocementation has emerged as a promising technique for soil engineering applications. There are chiefly two methods by which MICP is applied for field applications including biostimulation and bioaugmentation. Although bioaugmentation strategy using efficient ureolytic biocementing culture of Sporosarcina pasteurii is widely practiced, the impact of native ureolytic microbial communities (NUMC) on $\mathrm{CaCO}_{3}$ mineralisation via S. pasteurii has not been explored. In this paper, we investigated the effect of different concentrations of NUMC on MICP kinetics and biomineral properties in the presence and absence of $S$. pasteurii. Kinetic analysis showed that the biocementation potential of $S$. pasteurii is sixfold higher than NUMC and is not significantly impacted even when the concentration of the NUMC is eight times higher. Micrographic results revealed a quick rate of $\mathrm{CaCO}_{3}$ precipitation by S. pasteurii leading to generation of smaller $\mathrm{CaCO}_{3}$ crystals $(5-40 \mu \mathrm{m})$, while slow rate of $\mathrm{CaCO}_{3}$ precipitation by NUMC led to creation of larger $\mathrm{CaCO}_{3}$ crystals $(35-100 \mu \mathrm{m})$. Mineralogical results showed the predominance of calcite phase in both sets. The outcome of current study is crucial for tailor-made applications of MICP.

Microbially induced calcium carbonate precipitation (MICP) is a ubiquitously recorded process in nature and is responsible for creation of numerous geological formations in terrestrial and marine environments ${ }^{1}$. Recently this process has been replicated in lab conditions for numerous engineering applications, as it leads to the formation of carbonate cement at ambient temperature conditions by harnessing the cementation potential of living microorganisms. The major applications include improvement of mechanical properties of soil ${ }^{2,3}$, bioremediation of heavy metals and radio nucleotides ${ }^{4-6}$, enhancement of oil recovery ${ }^{7}$, repair of concrete cracks ${ }^{8,9}$, and sequestration of atmospheric $\mathrm{CO}_{2}{ }^{10}$ The chief benefit of this bio-mimicked cementation process includes self-healing ability, eco-friendliness, recyclability, and low viscosity paving the way for deeper penetration ${ }^{11}$.

MICP/Biocementation occurs via various metabolic pathways of bacteria such as ureolysis, denitrification, sulfate reduction, and iron reduction ${ }^{12}$. Amongst the different pathways, MICP via ureolytic pathway is the most widely explored route because of its straightforwardness, efficacy, short time, and no excess production of protons $s^{13,14}$. In the microbial ureolytic pathway, urea is hydrolysed into ammonia and carbon dioxide by the action of urease $e^{2}$. Subsequently, these products equilibrate in water to form bicarbonate, ammonium, and hydroxide ions, which elevate the $\mathrm{pH}$ of the microenvironment around the bacteria (Eq. 1). An increase in $\mathrm{pH}$ favors the equilibrium shifts from bicarbonate ions to carbonate ions. The formed carbonate ions then precipitate as calcium carbonate on the bacterial surface in the presence of calcium ${ }^{2}$ (Eq. 2).

$$
\begin{aligned}
& \mathrm{Co}\left(\mathrm{NH}_{2}\right)_{2}+2 \mathrm{H}_{2} \mathrm{O} \rightarrow \mathrm{HCO}_{3}^{2-}+2 \mathrm{NH}_{4}^{+}+\mathrm{OH}^{-} \\
& \mathrm{Ca}^{2+}+\mathrm{CO}_{3}^{2-}+\text { bacteria } \rightarrow \text { bacteria }-\mathrm{CaCO}_{3} \downarrow
\end{aligned}
$$

For applications of MICP in soils, especially in the field, there are two modes by which calcifying bacteria are supplemented: biostimulation (enrichment of native population) or bioaugmentation (supplementation of efficient foreign bacteria). The biostimulation approach deals with the modification of existing field conditions

${ }^{1}$ Bhupat and Jyoti Mehta School of Biosciences, Indian Institute of Technology Madras, Chennai 600036, India. ${ }^{2}$ School of Civil and Mechanical Engineering, Curtin University, Perth, WA 6102, Australia. ${ }^{\square}$ email: navdeep.dhami@curtin.edu.au 
by altering the nutrients, substrates, and electron acceptors to enrich the native microorganisms for accelerating the $\mathrm{CaCO}_{3}$ precipitation; whereas, bioaugmentation includes the addition of highly potential ureolytic and cementing strains especially Sporosarcina pasteurii into the fields ${ }^{5,32-35}$. Comparing these two approaches, MICP through bioaugmentation has a major advantage as it is a rapid process. This benefit makes this approach quite attractive for engineering applications, despite having the limitation of cost factor for preparation and transport of bacterial cultures ${ }^{34}$. On the other hand, biostimulation utilizes native bacteria making the MICP process both economically and environmentally viable ${ }^{34}$. Furthermore, the stimulation approach may eliminate the possible ecological impacts caused by a non-indigenous bacterial introduction in the applied soil environment, but the process rate is generally slow in comparison to the bioaugmentation approach ${ }^{36}$. The studies conducted on utilisation of both the approaches for improving the soil engineering properties reported that changes in solution chemistry and distribution of $\mathrm{CaCO}_{3}$ precipitate occurred invariably in 1-m soil column during biostimulation ${ }^{36}$; however, bioaugmentation with $S$. pasteurii led to significant improvement in strength, stiffness, load-bearing capacity and hydraulic conductivity of the soil ${ }^{12,36,37}$. Although researchers have demonstrated biogeochemical changes during the biostimulation approach, not much has been investigated on the impact of native ureolytic microbial communities (NUMC) on the performance of $S$. pasteurii and how these communities perform in comparison to this high urease producing culture ${ }^{36}$. Also, the concentration of NUMC changes vastly in the field and may affect the kinetics of the $\mathrm{CaCO}_{3}$ process, its mineralogy, and morphology which are the determining factors for the success of biocementation ${ }^{22}$.

Theoretical quantification methods and kinetic models are useful to predict the efficacy of the MICP process and to develop practical guidelines for field applications. There are studies in which theoretical models have been developed to quantify the $\mathrm{CaCO}_{3}$ precipitation efficacy in soil engineering ${ }^{56}$ and crack repair applications ${ }^{58}$. In MICP, the kinetics of the $\mathrm{CaCO}_{3}$ precipitation depends on the urease production of the bacteria and decides the overall efficacy of biocementation. Both kinetics of $\mathrm{CaCO}_{3}$ precipitation and urease production of the bacteria are influenced by both abiotic and biotic factors including temperature, $\mathrm{pH}$, aeration, nutrient availability, bacterial concentration, and type of bacteria or microbial population ${ }^{15-21}$. For instance, the urease activity and rate of $\mathrm{CaCO}_{3}$ precipitation at $30^{\circ} \mathrm{C}$ were reported to be higher than the observations at $15^{\circ} \mathrm{C}^{54}$. Besides, aerated conditions yielded a higher percentage of $\mathrm{CaCO}_{3}$ than unaerated conditions ${ }^{20}$, and the study also attempted to increase the urease production for improving the process by changing the nutrient concentration, especially urea $(0$ to $40 \mathrm{~g} / \mathrm{L})$ in the medium ${ }^{55}$. The influence of concentration of bacteria and urease enzyme is reflected in the kinetic constant of the $\mathrm{CaCO}_{3}$ precipitation in terms of first-order rate constant of 0.002 to $0.60 \mathrm{~h}^{-122-25}$. Further, the kinetics of the process also control the morphological and nanomechanical properties of the precipitated $\mathrm{CaCO}_{3}$; the slow rate of precipitation leads to the production of larger-sized crystals that are relatively stable compared to the smaller crystals formed at a high rate of precipitation ${ }^{26,27}$.

In general, microbially induced $\mathrm{CaCO}_{3}$ precipitate is a cohesive material ${ }^{2}$ and exists in different crystalline phases including calcite, vaterite, aragonite, monohydrocalcite, and ikaite ${ }^{1}$. The sizes of these crystals vary from 5 to $100 \mu \mathrm{m}$ along with variations in their nanomaterial properties ${ }^{28-30}$. Essential properties such as size, shape, stability, solubility, and hardness of the $\mathrm{CaCO}_{3}$ crystals determine the efficacy of MICP in engineering applications. For example, the conservation of building materials required more stable calcite than metastable vaterite and larger rhombohedral crystals $(100-150 \mu \mathrm{m})$ are more preferable in soil stabilization applications ${ }^{31}$. Even though studies utilized biostimulation and/or bioaugmentation approaches in MICP applications ${ }^{32-38}$, but very little information is available on these aspects including the impact of native ureolytic communities on MICP kinetics with and without $S$. pasteurii, the effect of the concentration of native communities on MICP, and the influence of kinetic factors on morpho-mineralogical properties of carbonate crystals. All these factors are crucial in determining the efficacy of biocementation for field applications. The purpose of this study is to (1) evaluate the influence of native ureolytic microbial community (NUMC) at varying concentrations on biocementation kinetics, (2) analyse the bioaugmentation potential of $S$. pasteurii in presence of different concentrations of native ureolytic microbial community and (3) investigate the effect of different cell concentrations of NUMC on morphological-mineralogical properties of $S$. pasteurii driven MICP.

We hypothesize that the outcome of this study will help to tailor MICP kinetics, morphology, mineralogy, and material properties of biomineralised crystals via both the stimulation and augmentation approach.

\section{Results}

Influence of the native ureolytic microbial community on the kinetics of calcium carbonate

precipitation. To investigate the influence of native ureolytic microbial community (NUMC) on calcium carbonate precipitation at varying concentrations $(0,0.1,0.2,0.4,0.8,1.6$, and $3.2 \mathrm{OD})$, soluble calcium concentration in the cementation medium was monitored for up to $288 \mathrm{~h}$ (at an interval of $12 \mathrm{~h}$ ). From Fig. 1a it can be observed that the soluble calcium concentration decreased over time in all the groups with varying rates except group A to which no NUMC was added. The calcium concentration decreased to $50 \%$ from the initial value for group B at 96th hour, for group C at 60th hour, for group D at 48th hour, for group E at 36th hour, and group F and $\mathrm{G}$ at the 24 th hour. At the end of the process, the soluble calcium ions in all the sets were exhausted, except in set $\mathrm{A}$.

Kinetic constants $\left(\mathrm{K}_{\mathrm{cal}}\right)$ of $\mathrm{CaCO}_{3}$ precipitation were used to further investigate the effect of various parameters on carbonate precipitation ${ }^{35}$. The monitored profiles were computationally fitted using Eq. (4) to calculate $\mathrm{K}_{\text {cal }}$ values (Fig. 1a). Table 1 shows $\mathrm{K}_{\mathrm{cal}}$ values at varying NUMC. It can be seen that the $\mathrm{K}_{\mathrm{cal}}$ values increased from group $\mathrm{A}\left(0 \mathrm{~h}^{-1}\right)$ to group $\mathrm{G}\left(0.078 \mathrm{~h}^{-1}\right)$ with increasing initial NUMC concentration. Further, the $\mathrm{K}_{\mathrm{cal}}$ values can be described by Michelis-Menten (MM) type Eq. (3). 
(a)

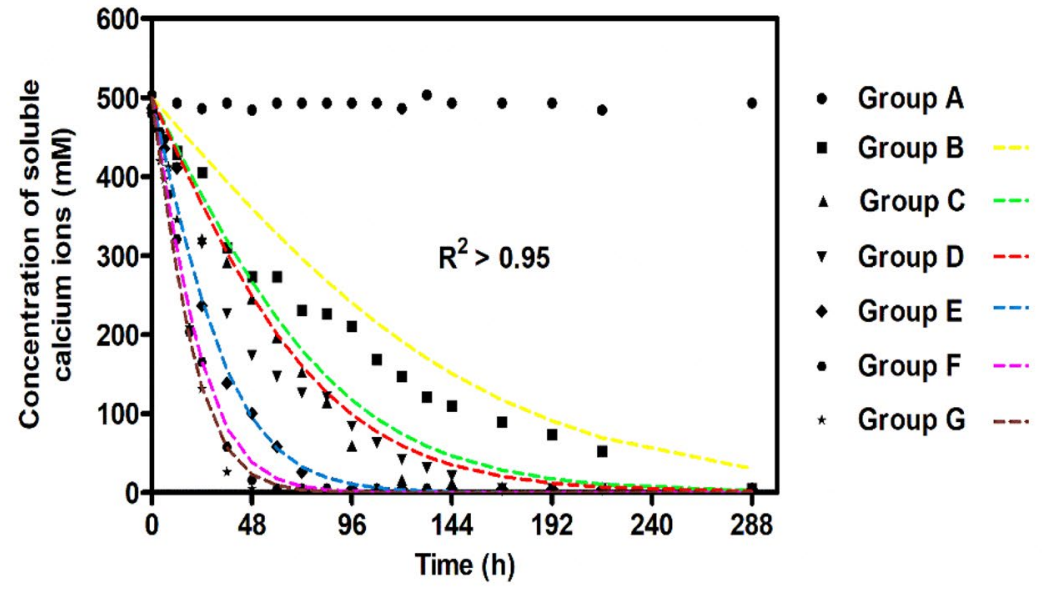

(b)

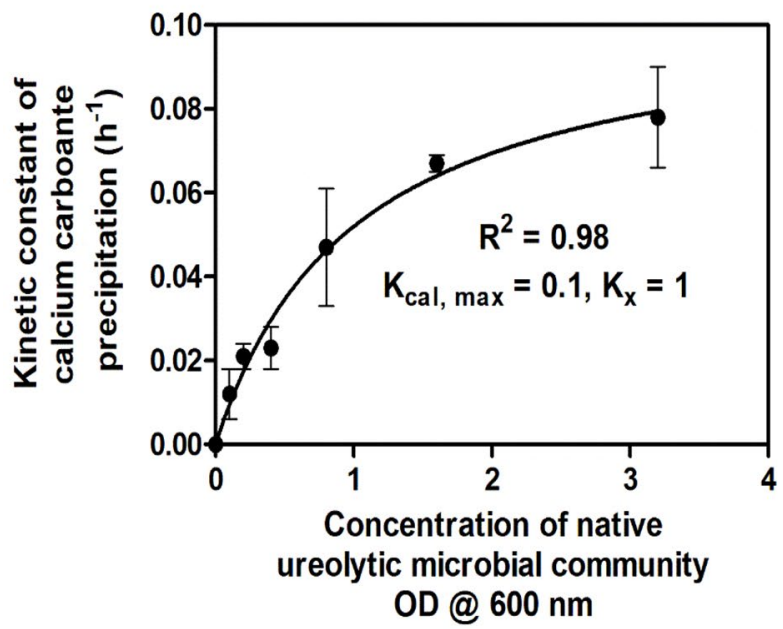

(c)

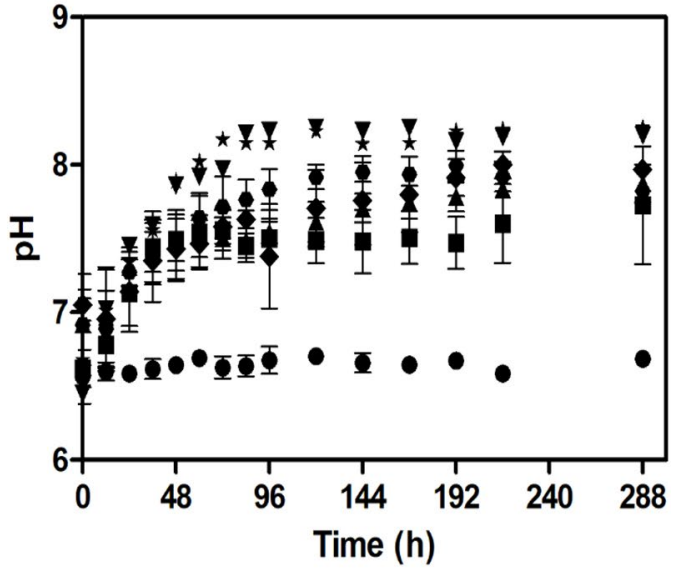

Figure 1. Concentration of soluble calcium ions over time (a). The relationship between the kinetic constant of $\mathrm{CaCO}_{3}$ precipitation and concentration of the native ureolytic microbial community (b). The variation of $\mathrm{pH}$ with time (c). Group A-0 OD NUMC, Group B-0.1 OD NUMC, Group C-0.2 OD NUMC, Group D-0.4 OD NUMC, Group E-0.8 OD NUMC, Group F-1.6 OD NUMC, and Group G-3.2 OD NUMC. NUMC Native Ureolytic Microbial Community. The coloured hidden lines are computationally fitted curves. Error bars in the figure indicate the standard deviation of three independent trials.

\begin{tabular}{|c|c|c|c|c|}
\hline S. No & $\begin{array}{l}\text { Native ureolytic microbial community } \\
\text { Group ID }\end{array}$ & $\begin{array}{l}\text { Concentration of NUMC } \\
\text { OD@ } 600 \mathrm{~nm}\end{array}$ & $\begin{array}{l}\text { Kinetic constant of calcium carbonate } \\
\text { precipitation }\left(h^{-1}\right)\end{array}$ & $\mathbf{R}^{2}$ \\
\hline 1 & Group A & 0 & 0 & NA \\
\hline 2 & Group B & 0.1 & $0.012 \pm 0.006$ & 0.97 \\
\hline 3 & Group C & 0.2 & $0.021 \pm 0.003$ & 0.98 \\
\hline 4 & Group D & 0.4 & $0.023 \pm 0.005$ & 0.98 \\
\hline 5 & Group E & 0.8 & $0.047 \pm 0.014$ & 0.99 \\
\hline 6 & Group F & 1.6 & $0.067 \pm 0.002$ & 0.99 \\
\hline 7 & Group G & 3.2 & $0.078 \pm 0.012$ & 0.98 \\
\hline
\end{tabular}

Table 1. The kinetic constant values of $\mathrm{CaCO}_{3}$ precipitation at varying native ureolytic microbial community concentration. NUMC Native Ureolytic Microbial Community, NA not applicable. \pm indicates the standard deviation of two independent trials. 
(a)
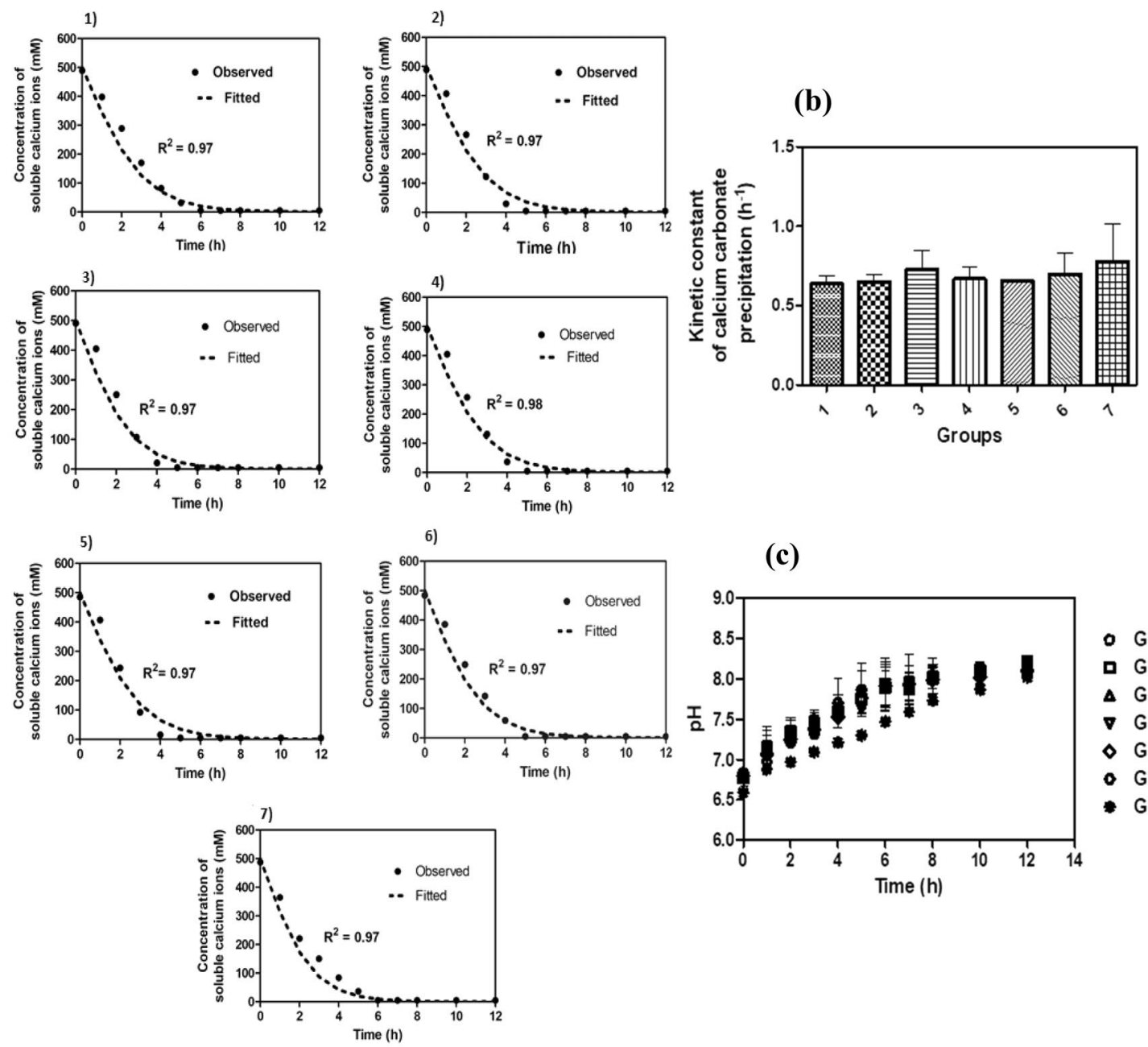

(c)

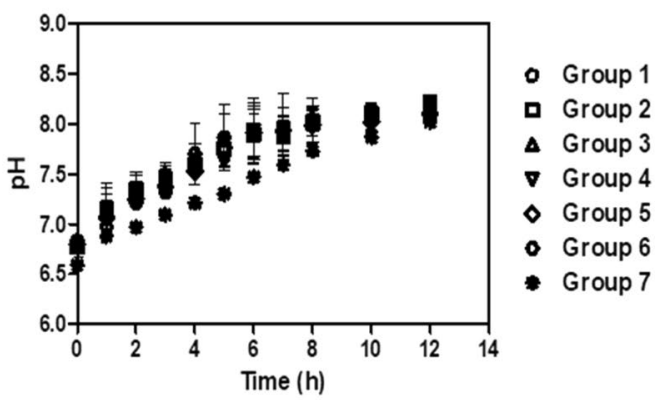

Figure 2. Concentration of soluble calcium ions over time-bioaugmentation (a), comparison of the kinetic constant of $\mathrm{CaCO}_{3}$ precipitation-bioaugmentation (b), the variation of $\mathrm{pH}$ with time (c). Group $1-0 \mathrm{OD}$ NUMC+ 0.4 OD S. pasteurii, Group 2-0.1 OD NUMC+0.4 OD S. pasteurii, Group 3-0.2 OD NUMC+ 0.4 OD S. pasteurii, 4) Group 4-0.4 OD NUMC+0.4 OD S. pasteurii, 0.8 OD NUMC+0.4 OD S. pasteurii, 1.6 OD NUMC+0.4 OD S. pasteurii, and 3.2 OD NUMC+0.4 OD S. pasteurii. NUMC Native Ureolytic Microbial Community. Bioaugmentation-(NUMC + S. pasteurii). Error bars in the Fig. $2 \mathrm{~b}$ and $2 \mathrm{c}$ indicate the standard deviation of two independent trials.

$$
K_{\text {cal }}=\frac{K_{\text {cal, } \max } X}{K_{x}+X}
$$

where $\mathrm{K}_{\mathrm{x}}$ is a constant, $\mathrm{X}$ is the NUMC concentration, and $\mathrm{K}_{\text {cal, max }}$ is the maximum kinetic constant for $\mathrm{CaCO}_{3}$ precipitation. When $\mathrm{K}_{\mathrm{x}}$ is equal to $\mathrm{X}$, the value of $\mathrm{K}_{\text {cal }}$ is equal to half of the $\mathrm{K}_{\text {cal max }}$. The observed values are $\mathrm{K}_{\mathrm{x}}=1$ $\mathrm{OD}$ and $\mathrm{K}_{\text {cal }, \max }=0.1 \mathrm{~h}^{-1}$ in this study. Figure $1 \mathrm{~b}$ shows $\mathrm{MM}$ type plot that relates $\mathrm{K}_{\text {cal }}$ with NUMC concentration.

Figure $1 \mathrm{c}$ shows the $\mathrm{pH}$ change over time in all the sets. In the cementation medium, $\mathrm{pH}$ was observed to be between 6.5 and 8.3 in all the groups throughout the process. It can be seen that the rate of $\mathrm{pH}$ change within the groups followed a similar trend except for the control group A.

Influence of the native ureolytic microbial community on augmented S. pasteurii. To investigate the influence of NUMC on S. pasteurii (bioaugmentation), soluble calcium concentration in the cementation medium was monitored over time and fitted with Eq. (4). Figure 2a shows both observed and fitted curves from groups 1 to 7 . From this figure, an exponential decrease of soluble calcium concentration was observed in all the groups with immediate effect upon the addition of NUMC and S. pasteurii. The concentration was recorded to be around zero at the 6th hour. From the fitted curves, the values of the kinetic constants for calcium carbonate precipitation were calculated (Table 2) and compared (Fig. 2b). From Table 2 it can be seen that the kinetic constant values are $0.64,0.65,0.64,0.73,0.67,0.66,0.70$, and $0.78 \mathrm{~h}^{-1}$ for the groups 1 to 7 , respectively, i.e., the values were distributed between 0.64 and $0.78 \mathrm{~h}^{-1}$. The change in the $\mathrm{pH}$ values of the cementation medium was also monitored (Fig. 2c) and the observed values were found to be between 6.5 and 8 for all the groups. 


\begin{tabular}{|c|c|c|c|c|c|}
\hline S. No & Group ID & $\begin{array}{l}\text { Concentration of NUMC } \\
\text { OD @ } 600 \mathrm{~nm}\end{array}$ & $\begin{array}{l}\text { Concentration of S.pasteurii OD@ } \\
600 \mathrm{~nm}\end{array}$ & $\begin{array}{l}\text { Kinetic constant of } \mathrm{CaCO}_{3} \\
\text { precipitation }\left(\mathrm{h}^{-1}\right)\end{array}$ & $\mathbf{R}^{2}$ \\
\hline 1 & Group 1 & 0 & \multirow{7}{*}{0.4} & $0.64 \pm 0.05$ & 0.97 \\
\hline 2 & Group 2 & 0.1 & & $0.65 \pm 0.05$ & 0.97 \\
\hline 3 & Group 3 & 0.2 & & $0.73 \pm 0.12$ & 0.97 \\
\hline 4 & Group 4 & 0.4 & & $0.67 \pm 0.07$ & 0.98 \\
\hline 5 & Group 5 & 0.8 & & $0.66 \pm 0.00$ & 0.97 \\
\hline 6 & Group 6 & 1.6 & & $0.70 \pm 0.13$ & 0.97 \\
\hline 7 & Group 7 & 3.2 & & $0.78 \pm 0.24$ & 0.97 \\
\hline
\end{tabular}

Table 2. The kinetic constants of calcium carbonate precipitation. \pm indicates the standard deviation of two independent trials. NUMC Native Ureolytic Microbial Community, S. pasteurii Sporosarcina pasteurii.

Morphology and Phase of $\mathrm{CaCO}_{3} . \quad \mathrm{CaCO}_{3}$ crystal morphology varies depending on the surface properties of the bacterial cell wall composition especially extracellular polymeric substances and the solution chemistry of the medium ${ }^{26}$. Hence, the shape and size of precipitated crystals were analysed via scanning electron micrography (Fig. 3). For groups 1 to 4, rhombohedral-shaped crystals of size 5-10 $\mu \mathrm{m}$ were observed for the samples collected at the 12 th hour. For group 5, the size of the individual and clustered rhombohedral-shaped crystals was found to be 15-25 $\mu \mathrm{m}$ for the samples collected at the 12th hour. For groups 6 and 7, for the samples collected at the 12 th hour the size of both the clustered rhombohedral-shaped crystals was $30-40 \mu \mathrm{m}$. SEM images showed a cluster of rhombohedral-shaped crystals for the samples collected at 288th hour for the groups B to G. The size of these crystals varied between 35 and $100 \mu \mathrm{m}$. The polymorph is a determining factor of strength and hardness of $\mathrm{CaCO}_{3}$ in MICP. Therefore, the qualitative and quantitative information of the $\mathrm{CaCO}_{3}$ crystals were obtained using the powdered XRD technique (for the groups B to $\mathrm{G}$ at 288th hour and the groups 1 to 7 at the 12th hour). Figure 4 shows the XRD spectrum of group B and the representative spectrums of all the other groups. Tables 3 and 4 show the morphology and phase analysis of native ureolytic microbial community and bioaugmentation studies. It was observed that only group B showed $2.3 \%$ of the vaterite phase of $\mathrm{CaCO}_{3}$ crystals and all observed crystal phases of all the groups were of the calcite phase.

\section{Discussion}

In this study, we investigated the effect of NUMC at varying concentrations on the biocementation potential of the most widely used biocementing culture $S$. pasteurii. We also compared the $\mathrm{CaCO}_{3}$ precipitation potential of NUMC at different concentrations in the presence and absence of $S$. pasteurii. The soluble calcium concentration was measured, and its kinetics was analysed using a logistic Eq. (4) to compare the biocementation potentials of NUMC and augmented S. pasteurii. $\mathrm{pH}$ was also monitored to identify the range that favours $\mathrm{CaCO}_{3}$ precipitation. SEM and XRD analyses were performed, which revealed the morphology (size and shape) and mineralogy of the crystals formed.

NUMC is capable of inducing $\mathrm{CaCO}_{3}$ precipitation in their microenvironment ${ }^{38}$. In Fig. 1a, the soluble calcium concentration decreased in all the groups. It could be due to carbonate ions generated in the MICP process during urea hydrolysis, which facilitates precipitation of soluble calcium around the bacterial cell wall in a cementation medium ${ }^{2}$. The complete exhaustion in the soluble calcium ions in the groups (group B-G) indicates that all the calcium in the medium is converted into $\mathrm{CaCO}_{3}$. Moreover, the supplied equimolar concentration of urea is enough for the complete conversion of $\mathrm{CaCO}_{3}$. The observed decrease in $\mathrm{CaCO}_{3}$ precipitation rate (Fig. 1a) is due to encapsulation of $\mathrm{CaCO}_{3}$ on the bacterial surface that limits the transport of nutrients transport including urea across the bacterial membrane ${ }^{39}$. The rate of soluble calcium depletion was observed to increase on increasing the NUMC concentration in the cementation medium. Increasing the NUMC concentration increases the total urease activity of the system, which in turn increases the soluble calcium depletion rate ${ }^{22}$. Moreover, the results show a positive correlation between $\mathrm{CaCO}_{3}$ precipitation rate and the cell concentration ${ }^{22-24}$. Furthermore, the relationship between $\mathrm{K}_{\text {cal }}$ and NUMC concentration could be used to design and develop a similar process for field applications. The kinetic constant $\mathrm{K}_{\mathrm{cal}, \mathrm{Max}}$ in the mathematical Eq. (3) denotes the maximum ability of the NUMC to achieve MICP at a faster rate, in this case, $0.1 \mathrm{~h}^{-1}$. The kinetic constant $\mathrm{K}_{\mathrm{x}}$ is equal to $1 \mathrm{OD}$, which indicates the concentration of NUMC required to achieve half the value of $\mathrm{K}_{\mathrm{cal}, \mathrm{Max}}$.

S. pasteurii is a widely employed bacterial strain for bioaugmentation of soil consolidation and stabilization process because of its high urease-producing potential ${ }^{40}$. Hence, this bacterium was chosen as the model organism for this study. Supersaturation Index (SI) is one of the key parameters for the initiation of $\mathrm{CaCO}_{3}$ precipitation ${ }^{5}$. Quick $\mathrm{CaCO}_{3}$ precipitation was observed for groups 1-7 in the cementation medium. This indicates that the cementation medium has reached the required SI in a short time. $\mathrm{pH}$ also affects the SI, which is evident from the reported result ${ }^{41}$ (Fig. 2c). Moreover, the ready availability of the positively charged calcium ions in the vicinity of the negatively charged bacterial surface could also favour quick $\mathrm{CaCO}_{3}$ precipitation ${ }^{3}$.

The observed $\mathrm{K}_{\text {cal }}$ value of group $1\left(0.64 \mathrm{~h}^{-1}\right)$ with S. pasteurii of $0.4 \mathrm{OD}$ was sixfold higher than the $\mathrm{K}_{\text {cal, Max }}$ $\left(0.1 \mathrm{~h}^{-1}\right)$ value of NUMC. This indicates that $S$. pasteurii has relatively high $\mathrm{CaCO}_{3}$ precipitation potential compared to NUMC. However, the observed results are in contrast to the reported studies that suggest biostimulation is the best possible approach for biocementation ${ }^{38,42}$. This could be due to the presence of different NUMC and varying study conditions between different research groups. The influence of varying concentrations of NUMC on the bioaugmentation potential of S. pasteurii was also investigated. However, no significant changes in the $\mathrm{K}_{\text {cal }}$ 

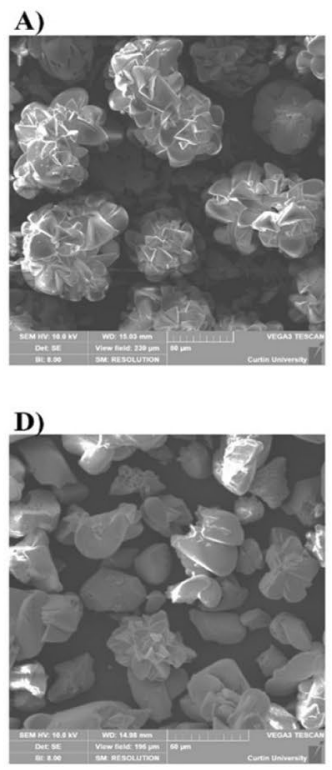
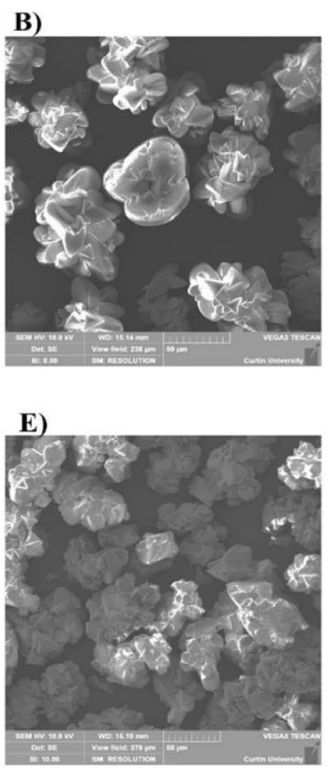
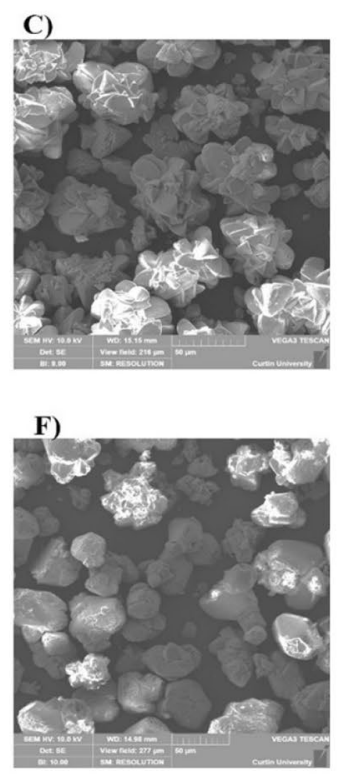

1)

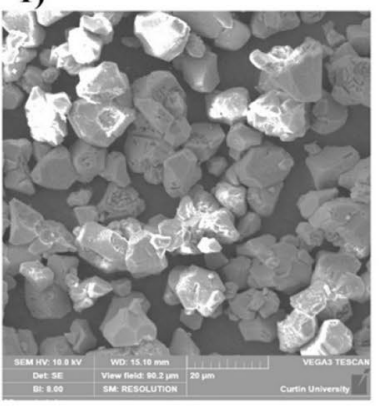

5)

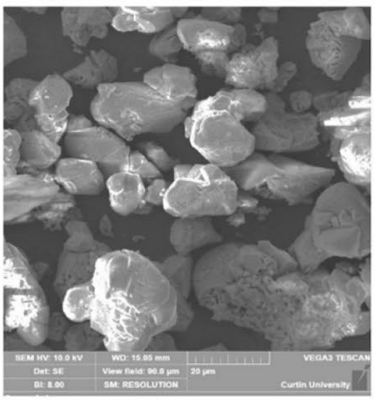

2)

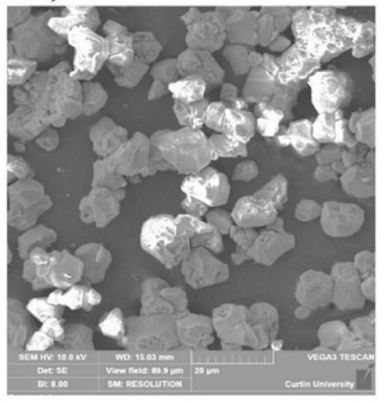

6)

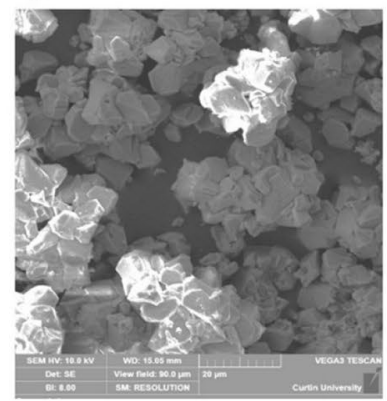

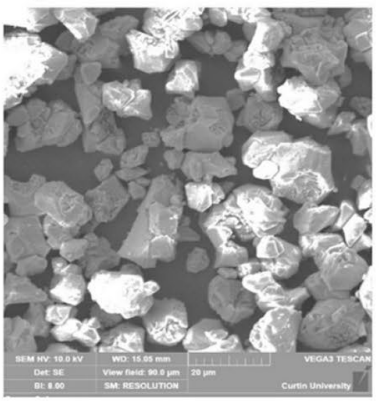

4)

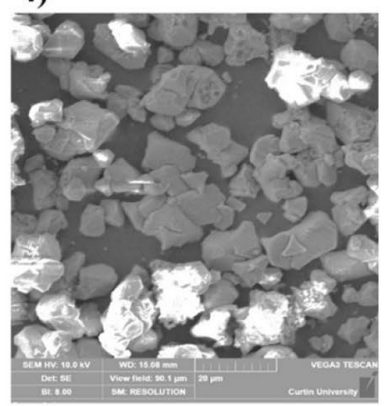

7)

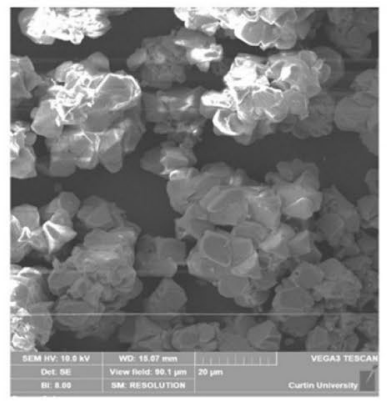

Figure 3. Scanning electron microscopy images of $\mathrm{CaCO}_{3}$ crystals. Groups $\mathrm{B}$ to $\mathrm{G}$ (NUMC) and 1 to 7 (bioaugmentation). (B) - 0.1 OD NUMC, (C)-0.2 OD NUMC, (D) - 0.4 OD NUMC, (E) - 0.8 OD NUMC, (F) - 1.6 OD NUMC, and (G) - 3.2 OD. (1) - 0 OD NUMC+0.4 OD S. pasteurii, (2) - 0.1 OD NUMC+0.4 OD S. pasteurii, (3)-0.2 OD NUMC+0.4 OD S. pasteurii, (4) Group 4-0.4 OD NUMC+0.4 OD S. pasteurii, (5) 0.8 OD NUMC+0.4 OD S. pasteurii, (6) 1.6 OD NUMC+0.4 OD S. pasteurii, and (7) 3.2 OD NUMC+0.4 OD S. pasteurii. NUMC Native Ureolytic Microbial Community and bioaugmentation-(NUMC + S. pasteurii).

values were observed within the groups when $\mathrm{K}_{\text {cal }}$ values were compared between groups 1 to 7 (Fig. 2b). This indicates that the presence of NUMC did not influence the $\mathrm{CaCO}_{3}$ precipitation potential of $S$. pasteurii even at a concentration as high as eightfold (group 7) over a period of two weeks in this study.

The $\mathrm{pH}$ of the cementation medium greatly influences the $\mathrm{CaCO}_{3}$ precipitation and also affects bacterial urease production ${ }^{41}$. In this study, the $\mathrm{pH}$ of the cementation medium of all the groups irrespective of the group type varied between 6.5 to 8.3. This indicates that the $\mathrm{CaCO}_{3}$ precipitation occurred between the observed $\mathrm{pH}$ range. Urease activity of the bacteria results in the generation of ammonium ions that in turn affects the $\mathrm{pH}$ of the cementation medium. The rate of $\mathrm{pH}$ change was observed to be comparatively high for groups 1 to 7 , which could be attributed to the high urease activity of $S$. pasteurit ${ }^{43}$. However, the same was not observed in groups A to $\mathrm{G}$ which could be attributed to the low urease activity of NUMC. 
a)

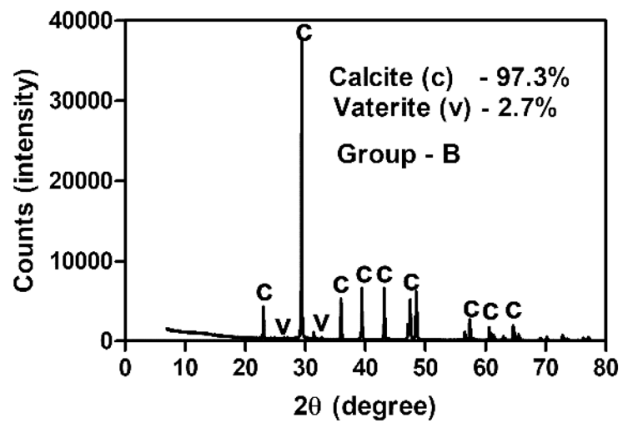

b)

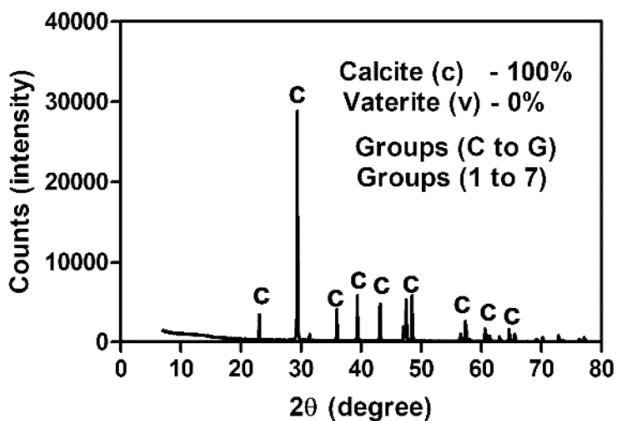

Figure 4. XRD spectrum of $\mathrm{CaCO}_{3}$ polymorphs. (a) Group B (NUMC) and (b) Groups $\mathrm{C}$ to G (NUMC) and 1 to 7 (bioaugmentation). Group B-0.1 OD NUMC, Group C-0.2 OD NUMC, Group D-0.4 OD NUMC, Group E-0.8 OD NUMC, Group F-1.6 OD NUMC, and Group G-3.2 OD NUMC. Group 1-0 OD NUMC+ 0.4 OD S. pasteurii, Group 2-0.1 OD NUMC+0.4 OD S. pasteurii, Group 3-0.2 OD NUMC+ 0.4 OD S. pasteurii, (4) Group 4-0.4 OD NUMC+0.4 OD S. pasteurii, 0.8 OD NUMC+0.4 OD S. pasteurii, 1.6 OD NUMC+ 0.4 OD S. pasteurii, and 3.2 OD NUMC+0.4 OD S. pasteurii. NUMC Native Ureolytic Microbial Community, bioaugmentation-(NUMC $+S$. pasteurii $)$.

\begin{tabular}{|c|c|c|c|c|c|c|}
\hline \multirow[b]{2}{*}{ S. No } & \multirow[b]{2}{*}{ Group ID } & \multirow{2}{*}{$\begin{array}{l}\text { Concentration of NUMC } \\
\text { OD @ } 600 \mathrm{~nm}\end{array}$} & \multirow{2}{*}{$\begin{array}{l}\text { The average size of the } \\
\text { crystal }(\mu \mathrm{m})\end{array}$} & \multirow[b]{2}{*}{ Shape } & \multicolumn{2}{|l|}{ Phase } \\
\hline & & & & & Vaterite (\%) & Calcite (\%) \\
\hline 1 & Group A & 0 & NA & NA & NA & $\mathrm{NA}$ \\
\hline 2 & Group B & 0.1 & $80-100$ & Cluster of rhombohedral & 2.3 & 97.7 \\
\hline 3 & Group C & 0.2 & $70-90$ & Cluster of rhombohedral & 0 & 100 \\
\hline 4 & Group D & 0.4 & $60-80$ & Cluster of rhombohedral & 0 & 100 \\
\hline 5 & Group E & 0.8 & $55-65$ & $\begin{array}{l}\text { Individual and Cluster of } \\
\text { rhombohedral }\end{array}$ & 0 & 100 \\
\hline 6 & Group F & 1.6 & $40-60$ & $\begin{array}{l}\text { Individual and Cluster of } \\
\text { rhombohedral }\end{array}$ & 0 & 100 \\
\hline 7 & Group G & 3.2 & $35-55$ & $\begin{array}{l}\text { Individual and Cluster of } \\
\text { rhombohedral }\end{array}$ & 0 & 100 \\
\hline
\end{tabular}

Table 3. The influence of native ureolytic microbial community concentration on the morphology and phase of $\mathrm{CaCO}_{3}$ crystals. NUMC Native Ureolytic Microbial Community, NA not applicable.

\begin{tabular}{|c|c|c|c|c|c|c|}
\hline S. No & Group ID & $\begin{array}{l}\text { Concentration of } \\
\text { NUMC } \\
\text { OD@ } 600 \mathrm{~nm}\end{array}$ & $\begin{array}{l}\text { Concentration of S. } \\
\text { pasteurii } \\
\text { OD@ } 600 \mathrm{~nm}\end{array}$ & $\begin{array}{l}\text { The average size of the } \\
\text { crystal }(\mu \mathrm{m})\end{array}$ & Shape & Phase \\
\hline 1 & Group 1 & 0 & \multirow{7}{*}{0.4} & $5-10$ & Rhombohedral & \multirow{7}{*}{ Calcite } \\
\hline 2 & Group 2 & 0.1 & & $5-10$ & Rhombohedral & \\
\hline 3 & Group 3 & 0.2 & & $5-10$ & Rhombohedral & \\
\hline 4 & Group 4 & 0.4 & & $5-10$ & Rhombohedral & \\
\hline 5 & Group 5 & 0.8 & & $15-25$ & $\begin{array}{l}\text { Individual and cluster of } \\
\text { rhombohedral }\end{array}$ & \\
\hline 6 & Group 6 & 1.6 & & $30-40$ & Cluster of rhombohedral & \\
\hline 7 & Group 7 & 3.2 & & $30-40$ & Cluster of rhombohedral & \\
\hline
\end{tabular}

Table 4. The morphology and phase characterization of $\mathrm{CaCO}_{3}$ crystals-bioaugmentation. NUMC Native Ureolytic Microbial Community.

The molecular mechanism of $\mathrm{CaCO}_{3}$ crystal nucleation, growth, and morphology (size and shape) in the biocementation process is a complex phenomenon. Nature of the bacterial community, solution chemistry of the cementation medium (supersaturation index), the concentration of nutrients, calcium, and $\mathrm{Mg}^{2+}$ ions significantly influence the crystal growth kinetics and characteristics ${ }^{44,45,47}$. In this study, groups $\mathrm{B}$ to $\mathrm{G}$ with only NUMC at different concentrations showed a cluster of rhombohedral-shaped crystals, sized 35-100 $\mu \mathrm{m}$ at 288 th hour. Whereas groups 1 to 4 with $S$. pasteurii in particular, yielded individual crystals of size $5-10 \mu \mathrm{m}$ at 12 th hour. A decrease in crystal size during bioaugmentation is due to the high driving force, which results in the fast attaining of the saturation state during $\mathrm{CaCO}_{3}$ precipitation. According to the classical nucleation theory: 
the nucleus size of the crystal decreases when the driving force to reach the saturation state for the precipitation increases ${ }^{46}$. This result is consistent with a previous study by Cuthbert and co-workers who reported that a higher initial saturation state influences the lower-sized crystals ${ }^{39}$.

The generation of ammonium ions and inorganic carbon due to the effective urea hydrolysis increases the $\mathrm{pH}$ and alkalinity of the cementation medium. It develops the oversaturated cementation solution that leads to the spontaneous $\mathrm{CaCO}_{3}$ precipitation ${ }^{5}$. It is possible to obtain different phases of $\mathrm{CaCO}_{3}$ including aragonite, calcite, vaterite, and two hydrated crystalline phases as monohydric calcite and ikaite in the MICP process ${ }^{1}$. This is because the polymorphism of $\mathrm{CaCO}_{3}$ is highly dependent on various parameters of the precipitation environment ${ }^{47,49-51}$. In general, many studies reported that the phase transition from metastable vaterite phase to more stable calcite phase during the $\mathrm{CaCO}_{3}$ precipitation process ${ }^{22,26}$. But, the specific phase preference by different bacterial cultures could depend on several parameters including the type of bacteria, specific amino acid sequences of urease, organic acid production, extracellular polymeric substances of the bacteria, the kinetics of the precipitation process, cementation medium composition, and other physicochemical parameters that affect supersaturation index of the solution ${ }^{47-51}$.

In this study, no visible $\mathrm{CaCO}_{3}$ crystals were observed in group A due to a lack of bacterial metabolic activity that leads to the undersaturation of the system. In the case of group B, besides $97.7 \%$ of calcite, $2.3 \%$ of vaterite form of $\mathrm{CaCO}_{3}$ crystals were formed at the end 288th hour. On the other hand, in all other groups including group $\mathrm{C}$ to $\mathrm{G}$ and group 1 to 7 only calcite form of $\mathrm{CaCO}_{3}$ crystals was observed at the end of precipitation (Fig. 4).

From the results, it is evident that calcite is the predominant polymorph of $\mathrm{CaCO}_{3}$ crystals in both cases. It is also evident that the presence of NUMC does not affect calcite formation. Moreover, the observed results follow the Ostwald rule of crystallization, which states that thermodynamically crystal formation favors the less soluble calcite than more soluble vaterite ${ }^{27}$. There could be a possible delay in the transformation of vaterite to calcite form when the rate of $\mathrm{CaCO}_{3}$ precipitation is slow. Hence, this could be attributed to the slow transformation of vaterite to calcite in groups B to $\mathrm{G}^{27}$. Nevertheless, only rhombohedral-shaped calcite form of crystals was observed in all the groups despite different bacteria employed in this study at the end of the process. These calcite form crystals have superior engineering properties (strength and stiffness) compared to vaterite and aragonite forms of $\mathrm{CaCO}_{3}$ crystals.

\section{Conclusions}

In this study, we investigated the influence of NUMC on the biocementation potential of the most widely used bacterial culture $S$. pasteurii. We evaluated the biogenic $\mathrm{CaCO}_{3}$ precipitation kinetics of NUMC at varying concentrations in the presence and absence of $S$. pasteurii along with its impact on the morpho-mineralogical characteristics of the precipitated carbonates. The concentration of cells has a major impact on the $\mathrm{CaCO}_{3}$ precipitation kinetics as well as morpho-mineralogical properties of precipitated carbonate crystals as observed in the case of NUMC. The rate of $\mathrm{CaCO}_{3}$ precipitation in the case of NUMC is very slow compared to $S$. pasteurii; and this can have a major impact on its application. $S$. pasteurii is highly efficient in biocementation even in the presence of native ureolytic cultures at different concentrations. $\mathrm{CaCO}_{3}$ precipitation kinetics of $S$. pasteurii was not found to impact significantly in the presence of NUMC; even when their concentration is eight folds higher. Although the rate of $\mathrm{CaCO}_{3}$ is low in the case of NUMC, but it has a positive impact on the quality of crystals. The size of calcite crystals in the case of NUMC with low metabolic activity is much higher (6-10 times) compared to smaller crystals formed by $S$. pasteurii. This demonstrates that it is crucial to have fundamental knowledge on the biocementation potential of native communities and the need for alternatives such as supplementation of S. pasteurii. The observed results of the current study demonstrate, for the first time, that the quantitative and qualitative properties of biocement can be tailored utilising the information of $\mathrm{CaCO}_{3}$ precipitation kinetics with native as well as augmented cultures. The findings of this study can pave way for several new possibilities for ureolysis driven biocementation in the area of advanced functional living materials.

\section{Materials and methods}

Bacteria, growth medium, and OD measurement. The bacteria used in this study are the Native Ureolytic Microbial Community (NUMC) $)^{52}$ and S. pasteurii (ATCC 11859). The NUMC is a mixture of four different ureolytic bacteria (BS1, BS2, BS3, and BS4) in equal proportions isolated from Brahmaputra riverbank soil (India) and enriched using a medium containing $13 \mathrm{~g} / \mathrm{L}$ nutrient broth and 5\% urea. From the previous study ${ }^{52}$, the BLAST analysis of the 16S rRNA sequence results showed that BS1 and BS2 are close relatives of Sporosarcina siberiensis. Whereas BS3 and BS4 are close relatives of Sporosarcina pasteurii, and Sporosarcina soli, respectively. The selected bacteria turned the urea agar base from yellow to pink colour within $12 \mathrm{~h}$ in the qualitative urease test. The steps are included in Fig. 5. Both S. pasteurii and NUMC were grown in Ammonium -Yeast extract medium (ATCC 1376) contains yeast extract ( $20 \mathrm{~g} / \mathrm{L})$, ammonium sulphate (10 g/L), and $0.13 \mathrm{M}$ tris base (pH 9) were maintained at $30^{\circ} \mathrm{C}$ and $180 \mathrm{rpm}$. The individual components of the growth medium were autoclaved and mixed after cooling under sterile conditions. To measure the concentration of the overnight grown NUMC and S. pasteurii, the media containing bacteria were centrifuged at $4500 \mathrm{rpm}$ for $10 \mathrm{~min}$ and the optical density was measured using a spectrophotometer (Thermo scientific, Genesis $10 \mathrm{~S}$ ) at $600 \mathrm{~nm}$ with $0.85 \%$ sodium chloride solution as blank.

Cementation medium and conditions. The cementation medium provides required nutrients and cementation components for NUMC and S. pasteurii. $100 \mathrm{~mL}$ of cementation medium was prepared by mixing $65 \mathrm{~mL}$ of autoclaved distilled water containing $0.2 \mathrm{~g}$ of yeast extract followed by the addition of required concentrations of NUMC and S. pasteurii cell pellet obtained after centrifugation (4500 rpm for $10 \mathrm{~min}$ ). Then 10 and 


\section{Collection of soil from Brahmaputra riverbank.}

(Soil contains native microorganisms including both non-ureolytic and ureolytic bacteria)

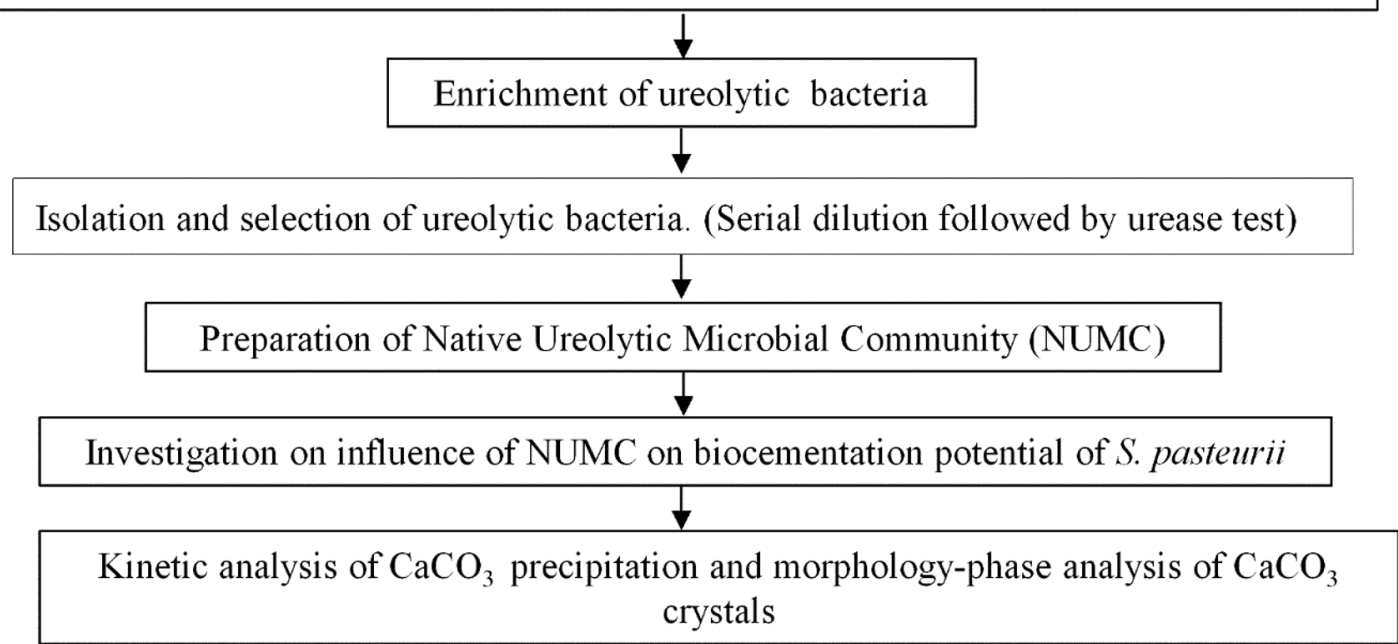

Figure 5. Schematic diagram of this study.

$25 \mathrm{~mL}$ of filter-sterilized $5 \mathrm{M}$ urea and $2 \mathrm{M}$ calcium chloride dihydrate solution were added, respectively. The cementation medium containing a bacterial pellet was maintained at $30^{\circ} \mathrm{C}$ and $180 \mathrm{rpm}$ in a shaker incubator.

Enumeration of bacterial concentration. The bacterial concentration was measured by the serial dilution method. Petri plates containing 1.5\% agar in ATCC 1376 media were used to spread the bacteria; 1 OD of bacteria in saline was found to contain cells equivalent to $4.5 \times 10^{8}$ cells $/ \mathrm{mL}$.

Study design. This study was designed to investigate the influence of NUMC on the biocementation potential of augmented $S$. pasteurii. The study was divided into two major groups. Each group is further subdivided into seven subgroups namely A to G and 1 to 7 . The groups A, B, C, D, E, F, and G have overnight grown NUMC pellet mixed with cementation medium at concentrations of $0,0.1,0.2,0.4,0.8,1.6$, and $3.2 \mathrm{OD}$, respectively. The groups $1,2,3,4,5,6$, and 7 contain fixed concentration of $S$. pasteurii (0.4 OD) and NUMC at concentrations of $0,0.1,0.2,0.4,0.8,1.6$, and $3.2 \mathrm{OD}$, respectively in the cementation medium. To monitor the process, $2 \mathrm{~mL}$ of samples were taken and centrifuged at $3000 \mathrm{rpm}$ for $10 \mathrm{~min}$ at regular intervals of time. The obtained supernatant was used to measure soluble calcium concentration and $\mathrm{pH}$ until the process was complete.

Measurement of soluble calcium ions and $\mathrm{pH}$. The soluble calcium ions were measured by using the complexometric titration procedure ${ }^{53} .40 \mu \mathrm{L}$ of the sample was diluted to $10 \mathrm{~mL}$ followed by the addition of 400 $\mu \mathrm{L} 1 \mathrm{~N}$ sodium hydroxide solution and a few drops of hydroxy naphthol blue disodium salt $(1 \% \mathrm{~W} / \mathrm{V})$ solution indicators. Then the mixture was titrated against $1 \mathrm{mM}$ EDTA disodium salt solution until the colour change from pink to blue was observed. The slope of the standard $\left(0-2.5 \mathrm{mM} \mathrm{CaCl}_{2}\right)$ was used to calculate the actual concentration of calcium ions in the sample. The change in $\mathrm{pH}$ during biocementation was recorded using a $\mathrm{pH}$ meter (Thermo scientific, Orion star, A211).

Morphology and phase analysis of $\mathrm{CaCO}_{3}$. The $\mathrm{CaCO}_{3}$ precipitate from the cementation medium was analysed at the end of the process. $30 \mathrm{~mL}$ of sample was taken was centrifuged at $4500 \mathrm{rpm}$ for $10 \mathrm{~min}$. The pellets obtained were washed twice with distilled water and dried at $37^{\circ} \mathrm{C}$ overnight. Then the dried crystals were subjected to scanning electron microscopy and XRD.

Morphology (size and shape). The variable pressure electron microscope (VP-SEM, Zeiss, EVO 40-XVP, 2008) was used to observe the size and shape of the $\mathrm{CaCO}_{3}$ precipitate. The samples were placed on carbonaluminum tape and coated using a carbon evaporative coater (Creissington, 2080C, 2011). The beam intensity and voltage were 8.0 and $10 \mathrm{kV}$, respectively with a working distance of around $15 \mathrm{~mm}$. The secondary electron imaging was used to obtain scanning electron micrographs. The sizes of the crystals from the micrographs were obtained using IMAJEJ (1.8.0 172) software.

Phase. Bruker D8 advance diffractometer with Ni-filtered $\mathrm{Cu} K \alpha$ radiation $(40 \mathrm{kV}, 40 \mathrm{~mA})$ over the range $7^{\circ}-120^{\circ} 2 \theta$, with a step size of $0.015^{\circ}$ was used to collect the XRD data. The powdered $\mathrm{CaCO}_{3}$ was resuspended in ethanol and deposited onto low-background holders. Further, the phase identification was done in Bruker EVA 5.2 using the Crystallography Open Database (COD) (http://www.crystallogrphy.net/). The phase quantification 
was done in Topas Academic 7 using the Rietveld method. Also, the crystal structures were identified from the COD.

Calculation of kinetic constants for calcium carbonate precipitation. Non-linear regression analysis was done using the curve fitting method. The exponential decrease of soluble calcium concentration over time was fitted with logistic Eq. (4) using the solver function in Excel (2016 MSO) to calculate the kinetic parameter called the kinetic constant of $\mathrm{CaCO}_{3}$ precipitation $\left(\mathrm{K}_{\text {cal }}\right)$. In curve fitting, the least-square method was used. The sum of squared values of the difference between the experimental and predicted value was fixed as the objective function, and $\mathrm{K}_{\mathrm{cal}}$ is the variable. $\mathrm{K}_{\mathrm{cal}}$ values were further used to compare the kinetics of $\mathrm{CaCO}_{3}$ precipitation at various operating conditions of this study. The logistic Eq. (4) is a slight modification of Eq. (3) from our previous study ${ }^{57}$.

$$
C_{c a l}(\mathrm{t})=2 C_{0} /\left(1+\mathrm{e}^{K_{\text {cal }} t}\right)
$$

where, $\mathrm{C}_{\mathrm{o}}$ is the initial concentration of calcium $(\mathrm{mM}), \mathrm{C}_{\mathrm{cal}}(\mathrm{t})$ is the soluble calcium concentration $(\mathrm{mM})$ at given time, $\mathrm{t}$ is the time $(\mathrm{h})$ and, $\mathrm{K}_{\mathrm{cal}}$ is the kinetic constant of calcium carbonate precipitation $\left(\mathrm{h}^{-1}\right)$.

Received: 5 July 2021; Accepted: 14 September 2021

Published online: 21 October 2021

\section{References}

1. Dhami, N. K., Reddy, M. S. \& Mukherjee, M. S. Biomineralization of calcium carbonates and their engineered applications: A review. Front. Microbiol. 4, 1-14 (2013).

2. Stocks-Fischer, S., Galinat, J. K. \& Bang, S. S. Microbiological precipitation of $\mathrm{CaCO}_{3}$. Soil Biol. Biochem. 31, 1563-1571 (1999).

3. Dejong, J. T., Mortensen, B. M., Martinez, B. C. \& Nelson, D. C. Bio-mediated soil improvement. Ecol. Eng. 36, 197-210 (2010).

4. Ferris, F. G., Phoenix, V., Fujita, Y. \& Smith, R. W. Kinetics of calcite precipitation induced by ureolytic bacteria at 10 to $20^{\circ} \mathrm{C}$ in artificial groundwater. Geochim. Cosmochim. Acta 68, 1701-1710 (2004).

5. Fujita, Y., Grant Ferris, F., Daniel Lawson, R., Colwell, F. S. \& Smith, R. W. Calcium carbonate precipitation by ureolytic subsurface bacteria. Geomicrobiol. J. 17, 305-318 (2000).

6. Kumari, D., Qian, X. Y., Pan, X., Achal, V. \& Li, Q. Microbially-induced carbonate precipitation for immobilization of toxic metals. Adv. Appl. Microbiol. 94, 79-108 (2016).

7. Wu, J., Wang, X. B., Wang, H. F. \& Zeng, R. J. Microbially induced calcium carbonate precipitation driven by ureolysis to enhance oil recovery. RSC Adv. 7, 37382-37391 (2017).

8. Ramachandran, S. K., Ramakrishnan, V. \& Bang, S. S. Remediation of concrete using micro-organisms. ACI Mater. J. 98, 3-9 (2001).

9. Van Tittelboom, K., De Belie, N., De Muynck, W. \& Verstraete, W. Use of bacteria to repair cracks in concrete. Cem. Concr. Res. 40, 157-166 (2010).

10. Mitchell, A. C., Dideriksen, K., Spangler, L. H., Cunningham, A. B. \& Gerlach, R. Microbially enhanced carbon capture and storage by mineral-trapping and solubility-trapping. Environ. Sci. Technol. 44, 5270-5276 (2010).

11. Phillips, A. J. et al. Engineered applications of ureolytic biomineralization: A review. Biofouling 29, 715-733 (2013).

12. Van Paassen, L. A., Ghose, R., van der Linden, T. J. M., van der Star, W. R. L. \& van Loosdrecht, M. C. M. Quantifying biomediated ground improvement by ureolysis: Large-scale biogrout experiment. J. Geotech. Geoenviron. Eng. 136, 1721-1728 (2010).

13. Whiffin, V. S., van Paassen, L. A. \& Harkes, M. P. Microbial carbonate precipitation as a soil improvement technique. Geomicrobiol. J. 24, 417-423 (2007).

14. Zhang, J. L. et al. Screening of bacteria for self-healing of concrete cracks and optimization of the microbial calcium precipitation process. Appl. Microbiol. Biotechnol. 100, 6661-6670 (2016).

15. Mortensen, B. M., Haber, M. J., DeJong, J. T., Caslake, L. F. \& Nelson, D. C. Effects of environmental factors on microbial induced calcium carbonate precipitation. J. Appl. Microbiol. 111, 338-349 (2011).

16. Martinez, B. C. et al. Experimental optimization of microbial-induced carbonate precipitation for soil improvement. J. Geotech. Geoenviron. Eng. 139, 587-598 (2013).

17. Soon, N. W., Lee, L. M., Khun, T. C. \& Ling, H. S. Factors affecting improvement in engineering properties of residual soil through microbial-induced calcite precipitation. Artic. J. Geotech. Geoenviron. Eng. 140, 04014006 (2014).

18. Zhao, Q. et al. Factors affecting improvement of engineering properties of MICP-treated soil catalyzed by bacteria and urease. J. Mater. Civ. Eng. 26, 04014094 (2014).

19. Oral, Ç. M. \& Ercan, B. Influence of $\mathrm{pH}$ on morphology, size and polymorph of room temperature synthesized calcium carbonate particles. Powder Technol. 339, 781-788 (2018).

20. Li, M., Wen, K., Li, Y. \& Zhu, L. Impact of oxygen availability on microbially induced calcite precipitation (MICP) treatment. Geomicrobiol. J. 35, 15-22 (2018).

21. Peng, J. \& Liu, Z. Influence of temperature on microbially induced calcium carbonate precipitation for soil treatment. PLoS ONE 14, e0218396 (2019).

22. Wen, K., Li, Y., Amini, F. \& Li, L. Impact of bacteria and urease concentration on precipitation kinetics and crystal morphology of calcium carbonate. Acta Geotech. 15, 17-27 (2020).

23. Okwadha, G. D. O. \& Li, J. Optimum conditions for microbial carbonate precipitation. Chemosphere 81, 1143-1148 (2010).

24. Lauchnor, E. G., Topp, D. M., Parker, A. E. \& Gerlach, R. Whole cell kinetics of ureolysis by Sporosarcina pasteurii. J. Appl. Microbiol. 118, 1321-1332 (2015).

25. Mitchell, A. C. et al. Kinetics of calcite precipitation by ureolytic bacteria under aerobic and anaerobic conditions. Biogeosciences 16, 2147-2161 (2019).

26. Heveran, C. M. et al. Engineered ureolytic microorganisms can tailor the morphology and nanomechanical properties of microbialprecipitated calcium carbonate. Sci. Rep. 9, 1-13 (2019).

27. Mitchell, A. C. \& GrantFerris, F. The influence of Bacillus pasteurii on the nucleation and growth of calcium carbonate. Geomicrobiol. J. 23, 213-226 (2006).

28. Hammes, F., Boon, N., De Villiers, J., Verstraete, W. \& Siciliano, S. D. Strain-specific ureolytic microbial calcium carbonate precipitation. Appl. Environ. Microbiol. 69, 4901-4909 (2003).

29. Rodriguez-Navarro, C., Jimenez-Lopez, C., Rodriguez-Navarro, A., Gonzalez-Muñoz, M. T. \& Rodriguez-Gallego, M. Bacterially mediated mineralization of vaterite. Geochim. Cosmochim. Acta 71, 1197-1213 (2007).

30. Chen, L. et al. Bacteria-mediated synthesis of metal carbonate minerals with unusual morphologies and structures. Cryst. Growth Des. 9, 743-754 (2009). 
31. Dhami, N. K., Mukherjee, A. \& Reddy, M. S. Micrographical, mineralogical and nano-mechanical characterisation of microbial carbonates from urease and carbonic anhydrase producing bacteria. Ecol. Eng. 94, 443-454 (2016).

32. Burbank, M. B., Weaver, T. J., Green, T. L., Williams, B. \& Crawford, R. L. Precipitation of calcite by indigenous microorganisms to strengthen liquefiable soils. Geomicrobiol. J. 28, 301-312 (2011).

33. Gomez, M. G. et al. Field-scale bio-cementation tests to improve sands. Proc. Inst. Civ. Eng. Ground Improve. 168, 206-216 (2015).

34. Gomez, M. G. et al. Large-scale comparison of bioaugmentation and biostimulation approaches for biocementation of sands. J. Geotech. Geoenviron. Eng. 143, 04016124 (2017).

35. Tobler, D. J. et al. Comparison of rates of ureolysis between Sporosarcina pasteurii and an indigenous groundwater community under conditions required to precipitate large volumes of calcite. Geochim. Cosmochim. Acta 75, 3290-3301 (2011).

36. Gomez, M. G., Graddy, C. M. R., Dejong, J. T. \& Nelson, D. C. Biogeochemical changes during bio-cementation mediated by stimulated and augmented ureolytic microorganisms. Sci. Rep. 9, 1-15 (2019).

37. Dhami, N. K., Alsubhi, W. R., Watkin, E. \& Mukherjee, A. Bacterial community dynamics and biocement formation during stimulation and augmentation: Implications for soil consolidation. Front. Microbiol. 8, 1267 (2017).

38. Raveh-Amit, H. \& Tsesarsky, M. Biostimulation in desert soils for microbial-induced calcite precipitation. Appl. Sci. 10, 2905 (2020).

39. Cuthbert, M. O. et al. Controls on the rate of ureolysis and the morphology of carbonate precipitated by S. pasteurii biofilms and limits due to bacterial encapsulation. Ecol. Eng. 41, 32-40 (2012).

40. Gomez, M. G., DeJong, J. T., Anderson, C. M., Nelson, D. C. \& Graddy, C. M. Large-scale bio-cementation improvement of sands. in Geotechnical and Structural Engineering Congress 2016-Proceedings of the Joint Geotechnical and Structural Engineering Congress 2016. 941-949. (American Society of Civil Engineers, 2016).

41. Hammes, F. \& Verstraete, W. Key roles of $\mathrm{pH}$ and calcium metabolism in microbial carbonate precipitation. Rev. Environ. Sci. Biotechnol. (2002).

42. Gomez, M. G., Graddy, C. M. R., DeJong, J. T., Nelson, D. C. \& Tsesarsky, M. Stimulation of native microorganisms for biocementation in samples recovered from field-scale treatment depths. J. Geotech. Geoenviron. Eng. 144, 04017098 (2018).

43. Bachmeier, K. L., Williams, A. E., Warmington, J. R. \& Bang, S. S. Urease activity in microbiologically-induced calcite precipitation. J. Biotechnol. 93, 171-181 (2002).

44. Okyay, T. O. \& Rodrigues, D. F. Optimized carbonate micro-particle production by Sporosarcina pasteurii using response surface methodology. Ecol. Eng. 62, 168-174 (2014).

45. Chekroun, K. B. et al. Precipitation and growth morphology of calcium carbonate induced by Myxococcus xanthus: Implications for recognition of bacterial carbonates. J. Sediment. Res. 74, 868-876 (2004).

46. Oxtoby, D. W. Homogeneous nucleation: Theory and experiment. J. Phys. Condens. Matter 4, 7627-7650 (1992).

47. Al Imran, M., Shinmura, M., Nakashima, K. \& Kawasaki, S. Effects of various factors on carbonate particle growth using ureolytic bacteria. Mater. Trans. 59, 1520-1527 (2018).

48. Lee, Y. S. \& Park, W. Current challenges and future directions for bacterial self-healing concrete. Appl. Microbiol. Biotechnol. 102, 3059-3070 (2018).

49. Sondi, I. \& Salopek-Sondi, B. Influence of the primary structure of enzymes on the formation of $\mathrm{CaCO}_{3}$ polymorphs: A comparison of plant (Canavalia ensiformis) and bacterial (Bacillus pasteurii) ureases. Langmuir 21, 8876-8882 (2005).

50. Rodriguez-Blanco, J. D., Shaw, S. \& Benning, L. G. The kinetics and mechanisms of amorphous calcium carbonate (ACC) crystallization to calcite, via vaterite. Nanoscale 3, 265-271 (2011).

51. Rodriguez-Navarro, C., Jroundi, F., Schiro, M., Ruiz-Agudo, E. \& González-Muñoz, M. T. Influence of substrate mineralogy on bacterial mineralization of calcium carbonate: Implications for stone conservation. Appl. Environ. Microbiol. 78, 4017-4029 (2012).

52. Dubey, A. A. et al. Biocementation mediated by native microbes from Brahmaputra riverbank for mitigation of soil erodibility. Sci. Rep. 11, 15250. https://doi.org/10.1038/s41598-021-94614-6 (2021).

53. APHA/AWWA/WEF. Standard methods for the examination of water and wastewater. Stand. Methods 541 (2012).

54. Sun, X., Miao, L., Tong, T. \& Wang, C. Study of the effect of temperature on microbially induced carbonate precipitation. Acta Geotech. 14, 627-638 (2019).

55. Sun, X., Miao, L., Tong, T. \& Wang, C. Improvement of microbial-induced calcium carbonate precipitation technology for sand solidification. J. Mater. Civ. Eng. 30, 04018301 (2018).

56. Martinez, B. C., DeJong, J. T. \& Ginn, T. R. Bio-geochemical reactive transport modeling of microbial induced calcite precipitation to predict the treatment of sand in one-dimensional flow. Comput. Geotech. 58, 1-13 (2014).

57. Murugan, R., Suraishkumar, G. K., Mukherjee, A. \& Dhami, N. K. Insights into the influence of cell concentration in design and development of microbially induced calcium carbonate precipitation (MICP) process. PLoS ONE 16, e0254536 (2021).

58. Sun, X., Miao, L., Wu, L. \& Wang, H. Theoretical quantification for cracks repair based on microbially induced carbonate precipitation (MICP) method. Cem. Concr. Compos. 118, 103950 (2021).

\section{Acknowledgements}

The authors would like to acknowledge the Microscopy and Microanalysis Facility, Curtin University, Western Australia for SEM and XRD analysis. The current study was funded by the Australian Research Council Linkage Project LP180100132.

\section{Author contributions}

R.M. performed the experiments; R.M., N.K.D., G.K.S., and A.M. contributed to experimental design and data analysis; R.M., and N.K.D. wrote the manuscript. All the authors reviewed the manuscript.

\section{Competing interests}

The authors declare no competing interests.

\section{Additional information}

Correspondence and requests for materials should be addressed to N.K.D.

Reprints and permissions information is available at www.nature.com/reprints.

Publisher's note Springer Nature remains neutral with regard to jurisdictional claims in published maps and institutional affiliations. 
(c) (i) Open Access This article is licensed under a Creative Commons Attribution 4.0 International cc) License, which permits use, sharing, adaptation, distribution and reproduction in any medium or format, as long as you give appropriate credit to the original author(s) and the source, provide a link to the Creative Commons licence, and indicate if changes were made. The images or other third party material in this article are included in the article's Creative Commons licence, unless indicated otherwise in a credit line to the material. If material is not included in the article's Creative Commons licence and your intended use is not permitted by statutory regulation or exceeds the permitted use, you will need to obtain permission directly from the copyright holder. To view a copy of this licence, visit http://creativecommons.org/licenses/by/4.0/.

(C) The Author(s) 2021 